\title{
Labilochus brevipalpis, a new genus and species with extremely long mouthparts (Hymenoptera, Ichneumonidae, Tersilochinae) from Mexico
}

\author{
Andrey I. Khalaim', Enrique Ruíz-Cancino², Juana María Coronado-Blanco² \\ I Zoological Institute, Russian Academy of Sciences, St. Petersburg, Russia $\mathbf{2}$ Facultad de Ingeniería y Ciencias, \\ Universidad Autónoma de Tamaulipas, Cd. Victoria, Mexico \\ Corresponding author: Andrey I. Khalaim (ptera@mail.ru)
}

Academic editor: G. Broad | Received 10 December 2016 | Accepted 8 March 2017 | Published 28 April 2017

http://zoobank.org/652B0BA2-9687-4C6A-9F55-92323D5889B0

Citation: Khalaim AI, Ruíz-Cancino E, Coronado-Blanco JM (2017) Labilochus brevipalpis, a new genus and species with extremely long mouthparts (Hymenoptera, Ichneumonidae, Tersilochinae) from Mexico. Journal of Hymenoptera Research 55: 121-127. https://doi.org/10.3897/jhr.55.11452

\begin{abstract}
Labilochus brevipalpis gen. \& sp. n. from northeast Mexico is described and illustrated. The new genus is distinguished from all other Tersilochinae taxa by its extremely long glossa and galeae in combination with short maxillary and labial palps, and both palps with reduced number of palpomeres. The genus also possesses a remarkable head, which is almost straight behind the eyes in dorsal view and with the occipital carina lacking laterally.
\end{abstract}

\section{Resumen}

Se describe e ilustra Labilochus brevipalpis n. gen. y sp. del noreste de México. El nuevo género se distingue de todos los taxa de Tersilochinae por su glosa y galeas extremadamente largas en combinación con los palpos maxilares y labiales cortos y con menos palpómeros. El género también tiene cabeza notable, es casi recta detrás de los ojos en vista dorsal y la carina occipital está ausente lateralmente.

\section{Keywords}

North America, taxonomy, new genus, new species 


\section{Introduction}

Tersilochinae is a moderately large ichneumonid subfamily distributed almost worldwide and comprising about 500 described and many undescribed species (Yu et al. 2012; Khalaim pers. obs.). Most host records of Tersilochinae are from various taxa of Coleoptera, but species of the genus Gelanes Horstmann are parasitoids of xyelid sawflies (Hymenoptera: Xyelidae) (Khalaim and Blank 2011; Horstmann 2013b), and some European species of Diaparsis Förster and Tersilochus Holmgren have been recorded as parasitoids of Tenthredinidae (Hymenoptera) and Eriocraniidae (Lepidoptera) (Yu et al. 2012).

Nearctic fauna of the subfamily was partly revised by K. Horstmann who examined types of 24 previously known Nearctic species (Horstmann 2001) and revised eleven genera with 74 species occurring in America north of Mexico (Horstmann 2010, 2012, 2013a, 2013b): Allophrys Förster (1 species), Allophroides Horstmann (6 species), Aneuclis Förster (4 species), Barycnemis Förster (13 species), Ctenophion Horstmann (1 species), Diaparsis Förster (12 species, including one introduced from Europe), Gelanes Horstmann (13 species), Phradis Förster (18 species), Sathropterus Förster (1 species), Spinolochus Horstmann (2 species) and Stethantyx (3 species, including one introduced from South America). Unfortunately, revisions of Nearctic species of two large genera, Probles Förster and Tersilochus Holmgren, were not finished due to the untimely death of $\mathrm{K}$. Horstmann.

In his revisions, $\mathrm{K}$. Horstmann identified specimens from Canada and USA but did not include material from Mexico, except for two species: Allophrys divaricata Horstmann, widely distributed from southern USA to Argentina and occurring in USA and northern Mexico, and Stethantyx nearctica Townes. Besides these two species, two new species of Barycnemis, the cosmopolitan Sathropterus pumilus (Holmgren), and five species of the large Neotropical genus Stethantyx (including one new species) were recorded or described from Mexico by A. Khalaim and co-authors (Khalaim 2002; Khalaim and Ruíz-Cancino 2013; Khalaim et al. 2015). Thus, only four genera of Tersilochinae and ten species are currently known from Mexico while a large number of genera and species occurring in Mexico are still undiscovered.

The aim of this work is to describe a new genus and species with bizarre mouthparts from Mexico.

\section{Materials and methods}

The new genus is known from two specimens, one female from the insect collection of the Universidad Autónoma de Tamaulipas, Cd. Victoria, Tamaulipas, México (UAT) and one male from the Townes collection, recently moved to the Utah State University, Logan, Utah, USA (EMUS).

Morphological terminology predominantly follows Townes $(1969,1971)$ with changes according to Khalaim (2011). Layer photographs were taken in the Texas A\&M University, Texas, USA (TAMU) with a DFC 295 digital camera attached to Leica stereomicroscope, and were combined using Helicon Focus software. 


\section{Taxonomy}

Labilochus Khalaim, gen. n.

http://zoobank.org/66B004C4-99DB-4FDA-8807-90855D90BFB7

Type species. Labilochus brevipalpis Khalaim \& Ruíz-Cancino, sp. n.

Composition. The new genus contains only the type species, L. brevipalpis, described below.

Morphological remarks. The genus is immediately recognisable by its extremely long glossa and galeae (Fig. 2) and reduced number of segments of the maxillary and labial palps. This is the only genus in the subfamily (and probably in the family) having such long glossa and galeae in combination with very short palps. Some taxa of Tersilochinae (e.g. genera Heterocola Förster and Palpator Khalaim, some species of Gonolochus Förster) possess long mouthparts including palps (especially maxillary palp), but none has the long glossa and galeae AND short palps in combination. The formula of maxillary and labial palps (3:2) is also unique within the subfamily; normally tersilochine species have 4-segmented maxillary and 3-segmented labial palps. The new genus is also distinct by having the head almost straight behind the eyes in dorsal view and the occipital carina lacking laterally.

Labilochus belongs to the Tersilochus group of genera, having a right-angled radial cell (Fig. 3) and the first metasomal segment with a distinct glymma joining by a deep furrow to the ventral part of the postpetiole. Within this group, Labilochus is most similar to the genus Probles Förster as it has a well-developed foveate groove on the mesopleuron (Fig. 5) and a long thyridial depression (Fig. 6).

Description. Head in dorsal view almost straight, weakly tapered behind eyes (Fig. 4); temple 0.9 times as long as eye width. Mandible with upper tooth much longer than lower tooth. Clypeus broad, lenticular, almost flat in lateral view, separated from face by weak furrow. Glossa and galeae very long, thin, equal in length, reaching past posterior end of hind coxa (Fig. 2); glossa not forked; maxillary palp 3-segmented, labial palp 2-segmented, both are very short (Fig. 2). Malar space 0.8 times as long as basal mandibular width in female and 0.5 times in male. Antennal flagellum slightly tapered towards apex, with 21-22 flagellomeres (Fig. 1). Occipital carina present dorsally and ventrally (next to mandibular base), absent laterally. Hypostomal carina absent.

Notaulus weakly impressed, without wrinkles. Scutellum with lateral longitudinal carinae developed in its anterior $0.3-0.4$ (Fig. 4). Foveate groove deep, sharp, with strong transverse wrinkles, strongly oblique, curved, not reaching epicnemial carina anteriorly (Fig. 5). Propodeum (Fig. 6) with transverse carina well developed, complete; basal area strongly impressed, elongate, distinctly widened anteriorly, 0.35 times as long as apical area, with basal longitudinal carinae indistinct. Propodeal spiracle separated from pleural carina by about 1.5 times diameter of spiracle. Apical area flat, pointed anteriorly; apical longitudinal carinae reaching transverse carina anteriorly, distinct posteriorly and rather weak anteriorly.

Fore wing (Fig. 3) with first and second abscissae of radius $(R s+2 r$ and $R s)$ meeting at right angle; both abscissae straight. Intercubitus and abscissa of cubitus between 
intercubitus and second recurrent vein (abscissa of $M$ between $2 r s-m$ and $2 m-c u$ ) not or weakly thickened. Metacarpus $(R 1)$ not reaching apex of wing. Hind wing with nervellus (cu1\&cu-a) vertical. Legs slender. Hind femur 4.6 times as long as broad and almost 0.85 times as long as tibia. Hind basitarsus 0.45 times as long as tibia (Fig. 2).

First tergite slender, postpetiole clearly separated from petiole (Fig. 6). Glymma distinct, situated in apical 0.6 of tergite, joining by distinct furrow to ventral part of postpetiole. Thyridial depression deep, about 2.5 times as long as broad (Fig. 6). Ovipositor long, evenly upcurved, slender, with very weak dorsal subapical depression; sheath about 3.5 times as long as first tergite.

Etymology. Named after its extremely long labium. Gender masculine.

\section{Labilochus brevipalpis Khalaim \& Ruíz-Cancino, sp. n.} http://zoobank.org/AD64ABAD-6B63-466D-ABFE-DF3FBF6F5FA1 Figs 1-6

Description. Female. Body length $4.0 \mathrm{~mm}$. Fore wing length $2.9 \mathrm{~mm}$.

Clypeus smooth, with very fine punctures in upper part. Antennal flagellum with 21 flagellomeres (Fig. 1); all flagellomeres (except basal and apical ones) more or less equally elongate, about 1.2-1.3 times as long as broad; flagellomeres 4 to 6 with subapical finger-shaped structures on outer surface. Face, frons and vertex with very fine, inconspicuous, dense punctures on smooth and weakly shining background. Temple polished, impunctate. Mesoscutum very finely punctate on smooth and weakly shining background. Mesopleuron mostly polished and impunctate. Foveate groove postero-ventrally covered by glue and indiscernible. Propodeum weakly shining, impunctate. Fore wing with intercubitus $(2 r s-m)$ somewhat longer than abscissa of cubitus between intercubitus and second recurrent vein (abscissa of $M$ between $2 r s-m$ and $2 m-c u$ ). First tergite 4.4 times as long as posteriorly broad, smooth (Fig. 6). Second tergite twice as long as anteriorly broad (Fig. 6).

Head black; clypeus brownish yellow in lower half, mandible brownish yellow with teeth blackish; glossa and palps yellow, remaining mouthparts dark brown or fuscous. Antennal flagellum black, scape and pedicel dark brown. Mesosoma black. Tegula yellowish. Pterostigma brown. Legs predominantly brown; all coxae black; mid and hind tibiae and tarsi fuscous; hind femur apically pale. First tergite black. Metasoma behind first tergite predominantly brownish yellow; tergite 2 in basal 0.2 , tergite 3 in basal 0.6, and following tergites more or less entirely dark brown to black dorsally.

Male. Labium almost reaching past posterior end of first metasomal tergite. Maxillary and labial palps not discernible, probably short. Antennal flagellum with 22 flagellomeres. Occipital carina dorsally fine but distinct, laterally and ventrally indiscernible. Mesopleuron very finely punctate peripherally, centrally (above foveate groove) polished and impunctate (Fig. 5). Fore wing (Fig. 3) with intercubitus (2rs-m) somewhat shorter than abscissa of cubitus between intercubitus and second recurrent vein (abscissa of $M$ between $2 r s-m$ and $2 m-c u$ ). Basal metasomal tergites slenderer than 


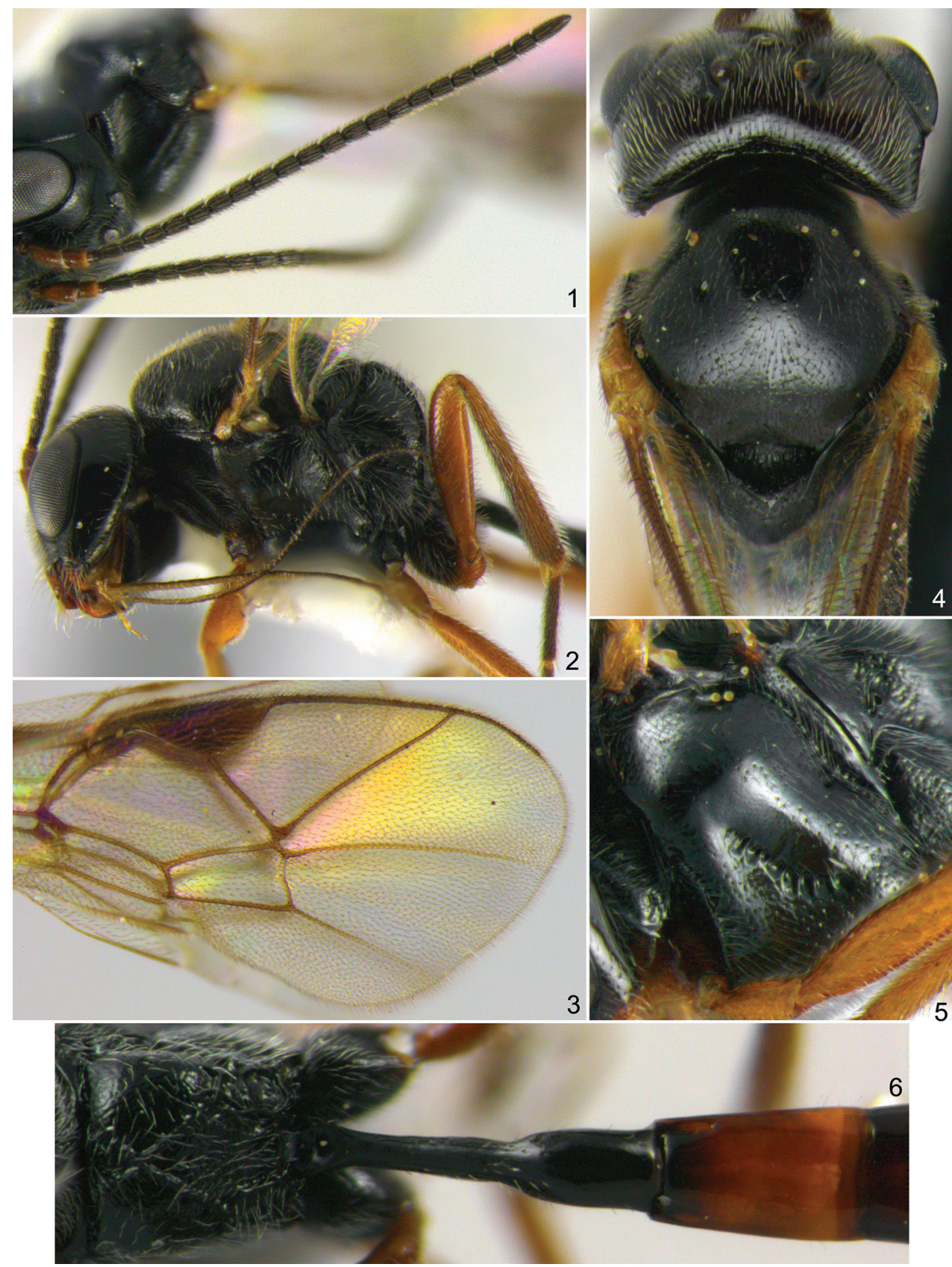

Figures I-6. Labilochus brevipalpis sp. n., holotype female (1,2, 6) and paratype male (3-5). I antenna $\mathbf{2}$ head and mesosoma, lateral view $\mathbf{3}$ fore wing $\mathbf{4}$ head and mesosoma, dorsal view $\mathbf{5}$ mesopleuron $\mathbf{6}$ propodeum and base of metasoma, dorsal view.

in female. Thyridial depression shallow. Fore and mid coxae slightly darkened with brown, tibiae and tarsi less infuscate than in female. Otherwise similar to female. 
Type material. Holotype female (UAT), Mexico, Tamaulipas, NE of Miquihuana, Rancho Obed Hernández, 2500 m, Malaise trap, 25.IX-7.X.2011, coll. E. RuízCancino \& J.M. Coronado-Blanco.

Paratype. 1 male (EMUS) Mexico, Nuevo León, $32 \mathrm{~km} \mathrm{~W}$ of Linares, San Pedro Iturbide, 26.X.1962, coll. H. \& M. Townes, "Probles sp. 37 Tow. 1969”.

Etymology. From the Latin brevis (small, short) and palpus (palp, feeler), after its short maxillary and labial palps.

\section{Discussion}

Mouthpart structure among parasitoid wasps was studied by Jervis (1998) who recognized seven functional types relating to the extraction of floral nectar in the families Braconidae and Ichneumonidae. According to Jervis, most Tersilochinae taxa have a type 1 mouthpart apparatus characterized by slightly to moderately elongated glossa and galeae, and glossa shallowly bilobed/forked at its tip and concealed by the galeae for most of its length in dried specimens; and a type 3, resembling type 1 but with maxillary palps markedly elongated, is known in the tersilochine genus Heterocola. Besides Heterocola, elongated mouthparts are present in the genus Palpator and some species of Gonolochus. Mouthpart apparatus in these taxa apparently also belongs to type 3 because the maxillary palps are always very long, with other mouthpart structures short or long.

The mouthpart apparatus of the genus Labilochus apparently belongs to type 1, but clearly differs from that of other ichneumonid and braconid wasps by the short palps in combination with the extremely long and slender glossa and galeae (in other taxa, if the galeae/glossae are long then the palps are also elongated). For example, in the family Ichneumonidae similar mouthparts are present in the ophionine genus Agathophiona Westwood comprising a single species occurring in Mexico (Townes 1971: 61), but in this genus the palps are also conspicuously elongated and the number of palpomeres are not reduced.

The mouthparts apparatus of Labilochus is unique among Tersilochinae, and perhaps among the family Ichneumonidae. Unfortunately, the genus is represented only by two dried specimens, female and male, deposited in two different collections, and their partition and preparation for detailed morphological study is not allowed.

\section{Acknowledgements}

We are thankful to David Wahl (EMUS) for the loan of valuable material, and John D. Oswald and Karen Wright (TAMU) for their kind help with taking colour photographs. Also we are grateful to Dmitri R. Kasparyan (Zoological Institute, Russian Academy of Sciences, St. Petersburg, Russia) for his important comments on the manuscript, and Gavin Broad (the Natural History Museum, London, UK) and an anonymous referee 
for their comments and language corrections. This work was supported by the Russian Foundation for Basic Research (grant no. 16-04-00197) and the PRODEP project "Taxonomical and biological studies of pests and natural enemies in Mexico".

\section{References}

Horstmann K (2001) Type revisions of Tersilochinae described from the Nearctic region (Hymenoptera, Ichneumonidae). Linzer Biologische Beiträge 33(1): 595-601.

Horstmann K (2010) Revisions of Nearctic Tersilochinae II. Genera Allophrys Förster, Barycnemis Förster, Ctenophion gen. nov., Sathropterus Förster, Spinolochus Horstmann and Stethantyx Townes (Hymenoptera, Ichneumonidae). Spixiana 33(1): 73-109.

Horstmann K (2012) Revisions of Nearctic Tersilochinae III. Genera Aneuclis Förster and Diaparsis Förster (Hymenoptera, Ichneumonidae). Spixiana 35(1): 117-142.

Horstmann K (2013a) Revisions of Nearctic Tersilochinae IV. Genus Phradis Förster (Hymenoptera, Ichneumonidae). Spixiana 36(1): 67-92.

Horstmann K (2013b) Revisions of Nearctic Tersilochinae V. Genera Allophroides Horstmann and Gelanes Horstmann (partim) (Hymenoptra, Ichneumonidae). Spixiana 36(2): 227-261.

Jervis M (1998) Functional and evolutionary aspects of mouthpart structure in parasitoid wasps. Biological Joumal of the Linnean Society 63(4): 461-493. https://doi.org/10.1111/j.1095-8312.1998.tb00326.x

Khalaim AI (2002) Two new species of the genus Barycnemis Förster from Mexico (Hymenoptera: Ichneumonidae, Tersilochinae). Zoosystematica Rossica 11(1): 167-169.

Khalaim AI (2011) Tersilochinae of South, Southeast and East Asia, excluding Mongolia and Japan (Hymenoptera: Ichneumonidae). Zoosystematica Rossica 20(1): 96-148.

Khalaim AI, Blank SM (2011) Review of the European species of the genus Gelanes Horstmann (Hymenoptera: Ichneumonidae: Tersilochinae), parasitoids of xyelid sawflies (Hymenoptera: Xyelidae). Proceedings of the Zoological Institute RAS, 315(2): 154-166.

Khalaim AI, Ruíz-Cancino E (2013) Mexican species of the genus Stethantyx Townes (Hymenoptera, Ichneumonidae, Tersilochinae). ZooKeys 360: 83-94. https://doi. org/10.3897/zookeys.360.6362

Khalaim AI, Ruíz-Cancino E, Coronado-Blanco JM (2015) First record of Sathropterus pumilus (Holmgren) (Hymenoptera: Ichneumonidae: Tersilochinae) from Mexico. Acta Zoológica Mexicana (NS) 31(1): 138-139.

Townes HK (1969) The genera of Ichneumonidae, Part 1. Memoirs of the American Entomological Institute 11: 1-300. https://doi.org/10.1007/bf02027741

Townes HK (1971) The genera of Ichneumonidae, Part 4. Memoirs of the American Entomological Institute 17: 1-372.

Yu DSK, van Achterberg C, Horstmann K (2012) Taxapad 2012, Ichneumonoidea 2011. Database on flash-drive. Ottawa, Ontario, Canada. 